\title{
PROBLEMATIKA DUALISME IDEOLOGI DAN KELEMBAGAAN PENDIDIKAN ISLAM
}

\author{
Fathorrahman Z \\ STAI Nazhatut Thullab Sampang \\ Email: rahmanzfathorbarokah@gmail.com
}

\begin{abstract}
Abstrak:
Dualisme pendidikan di Indonesia telah menjadi dilema yang belum dapat diselesaikan hingga sekarang. Dualisme ini tidak hanya berkenaan dengan sistem pengajarannya tetapi juga menjurus pada keilmuannya. Pola pikir yang sempit cenderung membuka gap antara ilmu-ilmu agama Islam dan ilmu-ilmu umum. Padahal dikotomi keilmuan ini justru menjadi garapan bagi para pakar pendidikan Islam untuk berusaha menyatukan keduanya. Dualisme pendidikan Islam juga muncul dalam bidang manajerialnya, khususnya di lembaga swasta. Lembaga swasta umumnya memiliki dua top manager yaitu kepala madrasah dan ketua yayasan (atau pengurus). Meskipun telah ada garis kewenangan yang memisahkan kedua top manager tersebut, yakni kepala madrasah memegang kendali akademik sedangkan ketua yayasan (pengurus) membidangi penyediaan sarana dan prasarana, sering di dalam praktik terjadi overlapping. Praktek manajemen di madrasah sering menunjukkan model manajemen tradisional, yakni model manajemen paternalistik atau feodalistik. Dominasi senioritas semacam ini terkadang mengganggu perkembangan dan peningkatan kualitas pendidikan.
\end{abstract}

Kata Kunci: idealisme, kelembagaan, pendidikan islam

\section{Abstract:}

The dualism of education in Indonesia has become a dilemma that has not been resolved until now. This dualism is not only concerned with the teaching system but also leads to its scholarship. A narrow mindset tends to open the gap between the sciences of Islam and the general sciences. Yet this dichotomy of science is actually a claim for Islamic education experts to try to unite the two. Islamic education dualism also emerged in the managerial field, especially in private institutions. Private institutions generally have two top managers: the head of the madrasah and the chairman of the foundation (or caretaker). Although there is a line of authority that separates the two top 
managers, ie the head of the madrasah holds academic control while the chairman of the foundation (caretaker) in charge of the provision of facilities and infrastructure, often in the practice of overlapping. Management practices in madrasas often show a traditional management model, the paternalistic or feudalistic management model. Such seniority dominance sometimes interferes with the development and improvement of the quality of education.

Keywords: idealism, institution, Islamic education

\section{Pendahuluan}

Seiring dengan era globalisasi dan tehnologi canggih, banyak persoalan-persoalan bangsa seperti dekadensi moral terjadi di mana-mana, angka kemiskinan semakin meningkat, praktek Korupsi, Kolusi, Nepotisme seakan menjadi menu spesial seharihari yang di konsumsi masyarakat melalui media cetak ataupun elektronik, ditambah lagi semakin sulitnya lapangan kerja, angka pengangguran semakin meningkat, dan banyak lagi persoalanpersoalan lain yang hingga detik ini belum sepenuhnya bisa diselesaikan dengan baik, bahkan kian hari kian meningkat dan semakin akut.

Disinyalir bahwa penyebab dari fenomena-fenomena di atas adalah kualitas sumberdaya manusia (SDM) yang relatif rendah, oleh karenanya pendidikan/ ilmu pengetahuan menjadi solusi yang baik guna meningkatkan kualitas SDM manusia, sehingga siap dan mampu bersaing baik ditingkat lokal, nasional maupun intersional dan diberbagai aspek, sosial, politik, ekonomi, dan budaya.

Sebenarnya peroblematika di atas bukan hal baru, tetapi merupakan persoalan klasik di nusantara ini. masyarakat (ilmuwan) dan pemerintah tidak tinggal diam menyaksikan fenomena-fenomena di atas. Telah banyak usaha-usaha dan terobosan yang dilakukan, misalnya, upaya peningkatan mutu lembaga pendidikan dari pengelolaan yang bersifat sentralistik menjadi desentralistik, kebijakan Manajemen Berbasis Sekolah (School Based Management) atau Sekolah Berbasis Masyarakat (School Based Community). Peningkatan kemandirian melalui kebijakan pemerintah tentang perguruan tinggi Badan Hukum Milik Negara (BHMN) atau Badan Hukum Pendidikan (BHP). Peningkatan mutu melalui kebijakan tentang Manajemen

Peningkatan Mutu Berbasis Sekolah/Madrasah (MPMBS/M), Kurikulum Berbasis Kompetensi (KBK), Kurikulum Tingkat Satuan 
Pendidikan (KTSP), Dewan Pendidikan, Komite Sekolah, Badan Standarisasi Nasional Pendidikan dan lain-lain. ${ }^{1}$

Berangkat dari pembahasan di atas, kiranya perlu untuk mengkaji madrasah sebagai bagian Pendidikan Islam (PI), baik melalui pendekatan landasan ideologis, atau pun historis, guna mendapatkan jawaban atau solusi dari persoalan-persoaan yang sedang dihadapi oleh PI, utamanya madrasah. Hal ini akan meminimalisir problem yang sedang dihadapi bangsa dan Negara yang nantinya diharapkan akan berimplikasi pada peningkatan kualitas sumber daya manusia melalui strategi pengembangan SDM yang baik.

\section{Landasan Ideologis Pendidikan Islam}

Proses pendidikan sebenarnya sudah ada dan dimulai sejak manusia pertama (Adam), proses pendidikan ini diisyaratkan oleh Allah kepada manusia (Adam) agar belajar, berfikir dan memahami tentang lingkungan kehidupan manusia. ${ }^{2}$ Sebagai mana firmannya:

'Dan Dia (Allah) mengajarkan kepada Adam Nama-nama (benda-benda) seluruhnya, kemudian mengemukakannya kepada Para Malaikat lalu berfirman: "Sebutkanlah kepada-Ku nama bendabenda itu jika kamu mamang benar orang-orang yang benar!" (QS. al- Baqarah: 31).

Dan Allah berfirman:

"Berkata (Sulaiman) : Wahai manusia, telah diajarkan kepada kami pengertian bunyi burung." (QS. An-Naml: 16).

bahkan ayat al-Qur'an yang pertama kali turun adalah

"Bacalah dengan (menyebut) nama Tuhanmu yang menciptakan" (QS. al-Alaq: 1).

"Iqra", memiliki arti membaca, menerangkan, menelaah, memahami dan mengkaji, bukan perintah sholat, puasa atau ibadah lainnya. Berangkat dari situlah manusia memikirkan, menelaah dan meneliti bagaimana strategi pelaksaan pendidikan yang baik agar tujuan yang diidealkan akan tercapai secara optimal.

Menyoroti asal usul pendidikan islam haruslah disertai dengan pemahaman tentang motivasi awal proses belajar mengajar yang dilakukan kaum muslimin sepanjang sejarah dengan penekanan pada periode awal. sebagai bukti, terdapat kaitan erat antara belajar dan penggerak utamanya, yaitu ketika Islam sebagai

\footnotetext{
1 Muhaimin, Manajemen Pendidikan, (Jakarta: Kencana, 2010), 69.

2 Jamaluddin, Darwis. Dinamika Pendidikan Islam, (Semarang: Rasail, 2010), 64.
} 
suatu agama menempatkan ilmu pengetahuan pada status yang sangat istimewa.

Allah berfirman:

"Allah akan mengangkat derajat orang - orang yang beriman dan orang-orang mempunyai ilmu" (QS. al-Mujadalah 58: 11)

Pendidikan islam pada priode awal sejarah islam, terinspirasi dari ayat-ayat al-qur'an dan hadist-hadist Rasulullah ketika beliau menyatakan kepada sahabat-sahabatnya, dan mengajak manusia percaya kepada Allah dan meninggalkan berhala. Pemikiran pendidikan yang bersumber pada dua tuntunan utama pendidikan islam di atas bukanlah fikiran pendidikan yang dikotomis sebagaimana dipahami oeh beberapa kalangan, tetapi pemikiran pendidikan yang integral dengan pemikiran politik, ekonomi, sosoial, sejarah dan peradaban, yang keseluruhannya membentuk kerangka umum ideologi islam.

Pemikiran pendidikan Islam dilihat dari al-Qur'an dan Hadist, tidaklah muncul sebagai pemikiran pendidikan yang terputus, terlepas hubungannya dengan masyarakat sebagaimana digambarkan oleh sebagian pemikir Islam, sehingga harus dipahami dengan baik bahwa Qur'an dan sunnah mempunyai nilainilai yang sangat ilmiah dan universal.

Dr. James E. Rjoyster dari Cleveland State University yang telah melakukan riset intensif tentang peran Nabi Muhammad sebagai seorang guru, teladan dan manusia ideal, membahas kesankesan kaum muslim terhadap Nabi mereka. Pada pengantar hasil penelitiannya ia menyatakan bahwa "mungkin tidak ada seorangpun dalam sejarah manusia yang lebih banyak diikuti daripada Nabi umat Islam (Muhammad). Kenyataan ini, sering kali dilupakan oeh orang-orang non-muslim, harus dipahami dalam rangka menilai secara tepat pengaruh Muhammad di antara mereka yang mengakuinya sebagai seorang nabi yang telah mengajarkan kebenaran dengan ucapan dan mengamalkan kebenaran itu dalam kehidupannya."3

Bahkan Nabi Muhammad dalam segala kata-kata, tingkah laku, dan segala keputusan yang diambilnya merupakan gambaran hidup terhadap pemikiran pendidikan Islam. Beliau adalah guru yang paling agung pada sekolah Islam, karena beliau lulusan sekolah Ilahiyah di Gua Hira yang telah meletakkan garis-garis

3 Abdurrahman Mas'ud, Menggagas Format Pendidikan Non Dikotomik, (Yogyakarta: Gama Media, 2002), 65-66. 
besar pemikiran pendidikan dalam al-Qur'an. ${ }^{4}$ Muhammad yang dikenal sebagai role model atau uswatun hasanah tak diragukan lagi sebagai contoh ideal, kiblat bagi kaum muslimin dan merupakan modeling yang sangat penting dalam pembentukan tradisi intelektual Islam.

\section{Pendidikan Islam di Indonesia}

Islam masuk ke Nusantara pada umumnya diyakini akhir abad ke-13. Menurut cacatan sejarah, sejak abad ke-15 masyarakat Nusantara sudah memiliki hubungan pendidikan dengan timur tengah. Hubungan tersebut berlanjut dan semakin intensif sampai abad ke-17. Hingga pada abad-18 hubungan keduanya mengalami kemunduran karena represi penjajah Belanda. baru akhir abad ke19 hubungan tersebut mengalami peningkatan karena perbaikan sarana angkutan khususnya pembukaan Terusan Suez (1864). ${ }^{5}$

Itu pun terjadi karena dengan politik tanam paksa, Kolonial Belanda menuai hasil dan atau mengeruk kekayaan Nusantara yang sangat melimpah, hingga khawatir situasi tersebut akan menyebabkan gerakan sosial yang akan meningkatkan perlawanan kepada mereka, sehingga Belanda mengeluarkan kebijakan baru, yaitu politik etis atau politik balas jasa.

Melalui politik etis-nya, tahun $1860 .{ }^{6}$ (sebelum Indonesia merdeka), Kolonial Belanda telah mengenalkan model pendidikan eropa, walaupun hanya terbatas pada elit politik lokal saja, seperti anak bupati (bangsawan), tetapi paling tidak hal tersebut menjadi momentum yang sangat penting dalam sejarah pendidikan di nusantara ini, karena kebijakan tersebut berimplikasi besar pada munculnya kesadaran nasionalisme dan buruknya penjajahan, sehingga pada saat itu muncul organisasi-organisasi kemasyarakatan dan lembaga pendidikan.

Di sisi lain, masyarakat juga ikut berpartisipasi dalam upaya penyelenggaraan pendidikan dengan alasan alamiah untuk memelihara nilai budaya, skill dan kekuasaan cultural mereka sendiri, sehingga tiap komunitas agama (Islam, Kristen, Hindu dan Budha) mempunyai lembaga pendidikan sendiri yang dikelola secara mandiri, termasuk di dalamnya komunitas muslim yang mengelola pendidikan berbasis masyarakat (community based

\footnotetext{
${ }^{4}$ Hasan Langgulung, Asas-asas Pendidikan Islam, (Jakarta: Alhusna Zikra, 2000), 134.

${ }^{5}$ Amin Abdullah, Pendidikan dan Upaya Mencerdaskan Bangsa, Paradigma Baru Pendidikan, (Jakarta: IISEP, 2008), 38.

6 Ibid., 37
} 
education). bahkan hal tersebut sebenarnya telah lama diselenggarakan oleh muslim Indonesia, yaitu setua sejarah perkembangan islam di nusantara ini. Seperti di aceh, ada rangkang, dayah dan meunasah, di minangkabau ada surau, di jawa terdapat pesantren, pondok, buslanul atfal, diniyah, dan sekolahsekolah islam didirikan dan dikembangkan masyarakat muslim sendiri. ${ }^{7}$

Pendidikan Islam di nusantara berjalan secara alami berdasarkan kedaerahan dan belumlah berpusat seperti sekarang ini. Tiap-tiap daerah melancarkan pendidikan dan pengajaran menurut keadaan daerahnya masing-masing, sehingga di Jawa tidak sama keadaanya dengan di Sumatera dan berlainan pula dengan di Sulawesi, Kalimantan, Maluku dan lain-lain. ${ }^{8}$

Eksistensi madrasah sebagai lembaga pendidikan Islam di Indonesia relatif lebih muda dibanding pesantren. Ia lahir pada abad 20 dengan munculnya Madrasah Manba'ul Ulum Kerajaan Surakarta tahun 1905 dan Sekolah Adabiyah yang didirikan oleh Syekh Abdullah Ahmad di Sumatera Barat tahun 1909. Madrasah berdiri atas inisiatif dan realisasi dari pembaharuan sistem pendidikan Islam yang telah ada. ${ }^{9}$

Setelah Indonesia merdeka, yaitu pada pemerintahan orde lama, perkembangan Pendidikan Islam Indonesia belum begitu optimal, karena 20 tahun pemerintahan Orde Lama praktis bergelut dengan persoalan politik dan kelembagaan Negara serta mengabaikan banyak aspek kehidupan lainnya, termasuk dalam hal pendidikan, akan tetapi walaupun demikian ada sisi yang menarik terkait dengan Pendidikan Islam Indonesia di era tersebut, yaitu dengan berdirinya Sekolah Tinggi Islam di Jakarta tanggal 8 juli 1946 oleh Badan Pengurus Sekolah Tinggi Islam (STI) yang kemudian hari ketika pemerintahan pindah ke Yogyakarta, STI juga pindah dan di kenal dengan Universitas Islam Indonesia (UII). ${ }^{10}$ Pada perkembangkan berikutnya, setelah berdirinya STI di atas, maka geliat semangat pendidikan makin meningkat, hal ini di tandai dengan berdirinya lembaga-lembaga pendidikan Islam di berbagai belahan tanah air Indonesia.

\footnotetext{
${ }^{7}$ Azyumardi Azra, Paradigma Baru Pendidikan Nasional, (Jakarta: Buku Kompas, 2006), 8.

8 Mahmud Yunus, Sejarah Pendidikan Islam di Indonesia, (Jakarta: Mutiara Sumber Widya, 1995), 216.

9 http://gurutrenggalek.blogspot.com/2009/12/Madrasah-sebagai-PusatPengetahuan_26.html, diakses Tanggal 03 Nopember 2016

${ }^{10}$ Amin Abdullah, 42-43.
} 
Kemudian pada masa Orde Baru, kebijakan pemerintah secara umum juga mempengaruhi perkembangan pendidikan islam, melalui SKB 3 menteri (Menteri Agama, Menteri Pendidikan dan Kebudayaan, dan Menteri dalam Negeri) tahun 1975 yang sebagian dari isianya adalah bahwa ijazah madrasah disamakan dengan ijazah sekolah umum yang sederajat, dan prosentasi materi pelajaran yang diberikan kepada madrasah, dari 100\% agama Islam menjadi 30\% materi agama dan 70\% materi umum: dengan terbentuknya lembaga pendidikan Islam formal mulai dari tingkat dasar sampai perguruan tinggi berindikasi bahwa: lembaga pendidikan Islam tidak hanya sebatas sebagai media dakwah, akan tetapi juga mempertimbangkan tuntutan pasar, sehingga masyarakat diorientasikan untuk memiliki keahlian, kepakaran dan keterampilan. ${ }^{11}$ pembangunan banyak berorentasi pada ekonomi, pendidikan belum mendapat porsi yang besar, sehingga kebijakan pemerintah belum seutuhnya memihak pada kepentingan pendidikan termasuk di dalamnya pendidikan Islam.

Walaupun demikian tetapi setidaknya ada sedikit angin segar bagi pendidikan Islam, karena madrasah sebagai lembaga pendidikan Islam saat itu ditempatkan sebagai pendidikan sekolah dalam sistem pendidikan nasional. Eksistensi madrasah sudah cukup kuat beriringan dengan sekolah umum. Di samping itu, munculnya SKB tiga menteri tersebut juga dinilai sebagai langkah positif bagi peningkatan mutu madrasah baik dari status, nilai ijazah maupun kurikulumnya. Di dalam salah satu diktum pertimbangkan SKB tersebut disebutkan perlunya diambil langkahlangkah untuk meningkatkan mutu pendidikan pada madrasah agar lulusan dari madrasah dapat melanjutkan atau pindah ke sekolah-sekolah umum dari sekolah dasar sampai perguruan tinggi.

Setelah runtuhnya pememerintah orde baru, maka orde reformasi kemudian yang memangku kebijakan di berbagai aspek pemerintahan, termasuk juga terkait dengan kebijakan pendidikan Islam. Kalau pada masa orde baru pendidikan agama Islam dapat dihubungkan dengan modernitas, di era reformasi terjadi tarik menarik antara unsur Islam, modernitas dan posmodernitas. Post modernitas sampai batas tertentu sebenarnya memberi cara bagaimana semestinya hubungan antara lembaga pendidikan agama diperhadapkan dengan modernitas, keduanya mempunyai

11 Muhaimin, Wacana Pengembangan Pendidikan Islam, (Surabaya: PSAPM, 2004), 176. 
daya penetrasi yang tidak dapat dibendung, masuk ke relungrelung keyakinan, perasaan dan pandangan dunia pada umumnya. Tuntutan pasar yang menawarkan pertarungan eksistensial yang kompetitif memaksa agama dan modernitas mengarahkan perkembangan lembaga pendidikan pada pilihan-pilihan subyektif yang rasional. Dan tuntutan terbesarnya adalah menjadikan lembaga pendidikan agama menjadi lembaga yang selama ini dikembangkan dalam lembaga umum.

Yang menjadi persoalan mendasar madrasah kemudian, adalah: satu sisi ia harus menguasai materi agama sebagai ciri has institusinya, sedangkan di sisi lain harus mengejar target kebutuhan pasar, masyarakat dan tuntutatan kebijakan pemerintah secara formal untuk menghasilkan out put sumber daya manusia yang multi talenta, ilmu agamanya bagus dan juga menguasai ilmuilmu pengetahuan yang lain.

Beberapa peristiwa di atas agaknya menjadi sumber inspirasi sehingga terdapat dualisme pemaknaan terhadap madrasah. Di satu sisi, madrasah diidentikkan dengan sekolah karena memiliki muatan secara kurikulum yang relatif sama dengan sekolah umum. Di sisi lain, madrasah dianggap sebagai pesantren dengan sistem klasikal yang kemudian dikenal dengan madrasah diniyah. Dengan demikian, sebagai sub sistem pendidikan nasional, madrasah belum memiliki jati diri yang dapat dibedakan dari lembaga pendidikan lainnya.

Model pendidikan madrasah di dalam perundang-undangan negara, memunculkan dualisme sistem Pendidikan di Indonesia. Dualisme pendidikan di Indonesia telah menjadi dilema yang belum dapat diselesaikan hingga sekarang. Dualisme ini tidak hanya berkenaan dengan sistem pengajarannya tetapi juga menjurus pada keilmuannya. Pola pikir yang sempit cenderung membuka gap antara ilmu-ilmu agama Islam dan ilmu-ilmu umum. Seakan-akan muncul ilmu Islam dan ilmu bukan Islam (kafir). Padahal dikhotomi keilmuan ini justru menjadi garapan bagi para pakar pendidikan Islam untuk berusaha menyatukan keduanya. ${ }^{12}$

Dualisme pendidikan Islam juga muncul dalam bidang manajerialnya, khususnya di lembaga swasta. Lembaga swasta umumnya memiliki dua top manager yaitu kepala madrasah dan ketua yayasan (atau pengurus). Meskipun telah ada garis kewenangan yang memisahkan kedua top manager tersebut, yakni kepala madrasah memegang kendali akademik sedangkan ketua

12 http://gurutrenggalek.blogspot.com/2009/12/ Madrasah-sebagai-PusatPengetahuan_26.html, diakses Tanggal 03 Nopember 2016 
yayasan (pengurus) membidangi penyediaan sarana dan prasarana, sering di dalam praktik terjadi overlapping. Praktek manajemen di madrasah sering menunjukkan model manajemen tradisional, yakni model manajemen paternalistik atau feodalistik. Dominasi senioritas semacam ini terkadang mengganggu perkembangan dan peningkatan kualitas pendidikan.

Munculnya kreativitas inovatif dari kalangan muda terkadang dipahami sebagai sikap yang tidak menghargai senior. Kondisi yang demikian ini mengarah pada ujung ekstrem negatif, hingga muncul kesan bahwa meluruskan langkah atau mengoreksi kekeliruan langkah senior dianggap tabiat su'ul adab. Kesenjangan antara madrasah swasta dan madrasah negeri pun tampaknya juga menjadi masalah yang belum tuntas diselesaikan. Gap tersebut meliputi beberapa hal seperti pandangan guru, sarana dan prasarana, kualitas input siswa dan sebagainya yang kesemuanya itu berpengaruh baik langsung maupun tidak langsung kepada mutu pendidikan. Yang demikian ini karena munculnya SKB tiga menteri tersebut belum diimbangi penyediaan guru, buku-buku dan peralatan lain dari departemen terkait.

Pendidikan Islam di Indonesia tidak jauh berbeda nasibnya dengan situasi pendidikan Islam di dunia. Dengan adanya dua model pendidikan agama: pesantren dan madrasah seperti yang ada sekarang ini, ternyata ummat Islam menghadapi kesulitan dalam mempertemukan imu-ilmu umum dengan ilmu-ilmu agama Islam.

Kalau kita lihat sejarah kelahiran pendidikan Islam pada awal abad ke-20, maka akan diketahui dengan jelas bahwa motivasinya betul-betul pragmatis, yaitu bagaimana mengimbangi pendidikan umum yang berkembang pesat semata-mata diorientasikan pada pemenuhan kebutuhan kolonialisme. Dari sini muncul keinginan memasukkan unsur agama dalam pendidikan umum, artinya memang sudah sejak lama diasumsikan tentang adanya dua lembaga pendidikan tersebut. Pada mulanya, penambahan mata pelajaran agama pada sekolah umum dipandang sebagai suatu terapi yang mujarab dalam membina periaku anak, namun belum berfikir untuk mengintegrasikan kedua jenis imu tersebut sesuai dengan iklim penjajahan pada waktu itu. ${ }^{13}$

Pada masa awal kemerdekaan, pemerintah dan bangsa Indonesia banyak diwarnai oleh warisan system pendidikan dan

13 M. Rusli Karim, Pendidikan Islam di Indonesia, (Yogyakarta: Tiara Wacana Yogya, 1991), 131. 
pengajaran yang dualististis, yaitu; system pendidikan dan pengajaran pada sekolah-sekolah umum yang skuler, tak mengenal ajaran agama, yang merupakan warisan dari pemerintah kolonial Belanda, dan sistem pendidikan dan pengajaran Islam yang tumbuh dan berkembang di kalangan masyarakat Islam sendiri, baik yang bercorak isolatif-tradisioal maupun yang bercorak sintetis dengan berbagai variasi pola pendidikan.

Perjalanan panjang sejarah pendidikan Indonesia di atas, melekat dan mewarnai pola fikir masyarakat, hingga detik ini masih kuat anggapan dalam masyarakat luas yang mengatakan agama dan ilmu adalah dua edentitas yang tidak bisa di pertemukan. Keduanya mempunyai wilayah sendiri-sendiri, terpisah antara satu dan lainnya, baik dari segi objek formalmaterial, metode penelitian, kriteria kebenaran, peran yang dimainkan oleh ilmuwan maupun status teori masing-masing bahkan sampai ke institusi penyelenggaranya.

Di Indonesia sampai saat ini, keilmuan Islam yang dikembangkan, masih dipengaruhi oleh adanya dikotomi ilmu, yang membagi ilmu umum dan ilmu agama, dengan institusi pendidikan yang berbeda pula, yang satu di bawah Kemendiknas dan satunya lagi di bawah Kemenag, dan celakanya ilmu agamalah yang dianggap ilmu keislaman, sehingga dalam studi keislaman, yang menjadi focus adalah kajian-kajian ilmu keagamaan, seperti kajian fiqih, ilmu kalam dan yang serumpunnya. Adapun kedokteran, arsitektur dan yang serumpunnya berada di luar kajian keilmuan Islam. ${ }^{14}$

Perjalanan sejarah pendidikan Islam di Indonesia memang tidak sama dengan sejarah yang dilalui umaat Islam di negaranegara lain. Misalanya di Turki yang berpenduduk sekitar 60 juta jiwa, kewajiban negara untuk menyelenggarakan pendidikan umum maupun agama diserakan sepenuhnya kepadea Kementrian Pendidikan. Sedangkan Indonesia, setelah enam bulan merdeka, Pemerintah Republik Indonesia meresmikan Kemenag tanggal 3 Januari $1946^{15}$ untuk melayani birokrasi berbagai keperluan umat Islam Indonesia. Dalam perjalannya yang panjang, Kemenag diberikan kepercayaan pemerintah untuk menyelenggarkan sendiri pendidikan agama dan tingkat Sekolah Dasar (MI), Sekolah Menengah Pertama (MTs), Sekolah Umum (MA) dan Perguruan Tinggi (IAIN dan STAIN).

\footnotetext{
${ }^{14}$ Musa Asy'arie, Filsafat Islam, (Yogyakarta: LESFI, 2008), 34.

15 Nanat Fatah Natsir, Strategi Pendidikan, (Yogyakarta: Pustaka Pelajar, 2010), 30 .
} 
Mengenai pengelolaan pendidikan agama diserahkan sepenuhnya kepada Kemenag dan tidak diserahkan kepada Kemendiknas memang menjadi perbincangan nasional hingga saat ini. Mengapa anggaran penyelenggaraan pendidikan agama masih dialokasikan di bawah mata anggaran sektor agama yang relatif kecil dan belum diambil dari bagian integral dari alokasi anggaran pendidikan?

Padahal data Kemenag menunjukan, bahwa MI swasta mendapai 95,2 persen: MIN hanya 14,8 persen. Keaadaan ini terbalik dengan SDN yang berjumlah 93,1 persen, berbanding SD Swasta 6,9 persen. Pada tingkat MTs, terdapat 75,7 persen MTs swasta berbanding 24.3 persen MTsN. Sedangkan SLTPN berjumlah 44,9 persen berbanding 55,9 persen SLTPN swasta. Pada tingkat selanjutnya, terdapat 70 persen MA swasta berbanding 30 persen MAN. Sedangkan SMUN berjumlah 30,5 persen berbanding SMU swasta sebanyak 69,4 persen. ${ }^{16}$

Dari data tersebut, dapat dipahami bahwa kontribusi lembaga pendidikan swasta (madrasah) terhadap perkembangan pendidikan di Indonesia sangat besar, tidak sebanding dengan apresiasi yang diberikan pemerintah, terutama mengenai kebijakan yang berkaitan dengan dana pendidikan, sehingga para penyelenggara pendidikan Islam sebagian menghadapi kesulitan dan keterbatasan dana, maka kepincangan anggaran bantuan atau subsidi dari pemerintah belum bisa meningkatkan mutu pendidikan Islam. Kebanyakan madrasah-madrasah swasta bukan hanya tidak mampu memiliki prasarana dan sarana pendidikan yang memadai, tetapi juga bahkan tidak mampu memberikan imbalan yang memadai bagi para guru dan tenaga kependidikan lainnya. Akibatnya, madrasah-madrasah swasta ini hanya mampu memiliki jumlah guru dan tenaga kependidikan lainnya secara sangat terbatas, dan itu pun dengan imbalan sekadarnya, bahkan sama sekali tidak ada imbalan apa-apa.

Dari sinilah muncul kecendrungan kuat bagi banyaknya guru dan tenaga kependidikan yang "salah kamar" (mismatch), "kualitas keilmuan yang tidak memadai" (unqualified atau underqualified). Hanya sekitar 20 persen dari total guru madrasah yang layak (qualified), sementara 20 persen mismatch, dan 60 belum atau tidak layak (under-qualified atau unqualified). ${ }^{17}$

\footnotetext{
${ }^{16}$ Azyumardi Azra, Paradigma Baru Pendidikan Nasional, (Jakarta: Buku Kompas, 2006), 8.

17 Ibid., 9
} 


\section{Solusi Alternatif bagi Madrasah}

Dari uraian di atas, kiranya dapat di usung sebuah gagasan sebagai solusi dari berbagai problem Madrasah di Indonesia guna mengasilkan sumberdaya manusia yang berkualitas, baik intelektual ataupun, spiritual di antaranya adalah:

\section{Akhiri Dikotomi Agama dan Ilmu dalam Praktik Pendidikan}

Aktifitas pendidikan dan keilmuan di Perguruan tinggi Umum dan Perguruan Tinggi Agama di tanah air mirip seperti pola kerja keilmuan awal abad renaissance hingga era revolusi informasi, yang sekarang ini mulai diratapi oleh banyak kalangan. Hati nurani terlepas dari akal sehat, Nafsu serakah menguasai perilaku cerdik pandai. Paraktik korupsi, kolusi dan nepotisme merajalela. Lingkungan alam rusak berat. Tindakan kekerasan dan mutual distrust mewabah di mana-mana. ${ }^{18}$

Jauh sebelumnya, dalam sejarah kependidikan Islam telah pula terpola pengembangan keilmuan yang bercorak Interalistik ensiklopedik di satu sisi, yang dipelopori oleh para ilmuwan seperti Ibnu Sina, Ibnu Khaldun, berhadapan dengan pola pengembangan keilmuan agama yang spesifik-parsialistik di sisi lain, yang dikembangkan oleh para ahli hadits dan ahli fiqih. Keterpisahan secara diametra antara keduanya dan sebab-sebab lain yang bersifat politis-ekonomis, berakibat pada rendahnya mutu pendidikan dan kemunduran dunia Islam pada umumnya. Dalam ketiga revolusi peradaban manusia, yaitu revolusi hijau, revolusi industri dan revolusi informasi, tidak ada satu pun ilmuwan Muslim yang tercatat namanya dalam lembaran tinta emas pengembang ilmu pengetahuan. Perkembangan dan pertumbuhan ilmu-ilmu secular sebagai simbol keberhasilan Perguruan Tinggi Umum yang tercerabut dari nilai-nilai akar moral dan etik kehidupan manusia di satu pihak, sementara di lain pihak, perkembangan dan pertumbuhan Perguruan Tinggi Agama yang hanya menekankan ilmu-ilmu keagamaan dan teks-teks keislaman normatif era klasik yang berdampak pada persoalan penciptaan tenaga kerja terampil dalam dunia ketenagakerjaan, menjadikan keduanya mengalami proses pertumbuhan yang tidak sehat serta membawa dampak negatif bagi pertumbuhan dan perkembangan kehidupan sosial-budaya, sosial-ekonomi, sosial-politik dan sosial keagamaan di tanah air.

18 Amin Abdullah, Islamic Studies di Perguruan Tinggi, (Yogyakarta: Pustaka Pelajar, 2006), 94. 
Tantangan di era globalisasi menuntut respons tepat dan cepat dari sistem pendidikan Islam secara keseluruhan. Jika kaum Muslimin tidak hanya ingin sekedar survive di tengah persaingan global yang semakin tajam dan ketat, tetapi juga berharap mampu tampil di depan, maka re-orientasi pemikiran mengenai pendidikan Islam dan rekonstruksi sistem dan kelembagaan, termasuk di dalamnya madrasah merupakan keniscayaan. Umat Islam tidak boleh berpangku tangan dan menonton dari luar seluruh perkembangan yang terjadi, dan malah semakin memperuncing dikotomi ilmu pengetahuan dengan memakai legitimasi agama secara spekulatif dan tidak bertanggung jawab.

Padahal paradigma konsep pendidikan dan keilmuan baru, bukan sekedar menggabungkan wahyu Tuhan dan temuan pikiran manusia (ilmu-ilmu holistic-integralistik), itu tidak akan berakibat mengecilkan peran Tuhan (sekularisme) atau mengucilkan manusia sehingga teraleniasi dari dirinya sendiri, dari masyarakat sekitar, dan lingkungan hidup sekitarnya. Diharapkan dengan konsep integralisme dan reintegrasi epistemologi keilmuan sekaligus akan dapat menyelesaikan konflik antar sekularisme ekstrim dan fundamentalisme negatif agama-agama yang rigid dan radikal dalam banyak hal.

Kondisi riil implementasi ilmu yang bercorak integralistik dapat kita lihat di antaranya dari ilmu Ekonomi Syariah, yang sudah nyata ada praktiknya penyatuan antara wahyu Tuhan dan temuan pikiran manusia. Misalanya BMI (Bank Muamalat Indonesia) Bank BNI Syariah, usaha-usaha agrobisnis, transportasi, kelautan, dan sebagainya. Sementara di sisi lain, agama menyediakan etika dalam perilaku ekonomi di antaranya adalah bagi hasil (al-mudharabah), dan kerjasama (al-musyarakah). Di situ terjadi proses objektifikasi dari etika agama menjadi ilmu agama yang dapat bermanfaat bagi orang dari semua penganut agama, non agama, atau bahkan anti-agama sekalipun.

Dari uraian di atas sangat jelas, bahwa pola fikir dikotomis dalam ideologi pendidikan Islam dan lembaga pendidikan Islam baik yang berkaitan dengan kurikulum, manajemen dan unsurunsur pendukung yang lain harus diminimalisir dan bahkan dibuang sejauh-jauhnya karena tidak dibenarkan menurut tinjauan agama Islam dan pola fikir (rasio) yang sehat.

\section{Reformasi Lembaga Pemerintah}

Kemenag sudah mulai mengelola lembaga pendidikan Islam sejak departemen ini berdiri. Padahal Lembaga pendidikan Islam 
yang dikelola oleh Kemenag, jika diprosentase mungkin tidak kurang dari $20 \%$ dari jumlah lembaga pendidikan yang ada di Indonesia, tetapi, ironis, lembaga-lembaga pendidikan itu lebih dari empat dasarwarsa tidak memperoleh anggaran pendidikan. Anakanak Muslim yang jumlahnya mencapai jutaan, tinggal di suatu Negara yang mayoritas penduduknya beragama Islam, tetapi lebih dari empat dasawarsa tidak memperoleh anggaran pendidikan, hingga sampai pada tahun 2007 Kemenag baru memperoleh anggaran pendidikan melalui kebijakan Pemerintah.

Ada beberap alternatif yang segera harus dilakukan di antaranya adalah; pertama, Tetap mempertahankan eksistensi suprastruktur Ditjen Binbaga, Kemenag, sedangkan penyelenggaraan pendidikan dilimpahkan kepada Pemda Tingkat II. Dasar pertimbangan alternatif pertama ini adalah bahwa Kemenag tetap memegang kewenangan dalam mengelola pendidikan agama dan pendidikan keagamaan sesuai dengan aspirasi masyarakat Muslim. Selain itu, pembinaan pendidikan agama dan keagamaan secara operasional akan sama dengan pembinaan pendidikan di sekolah umum. Dengan demikian, maka Kemenag memiliki kekuatan yang berkaitan dengan pemiliharaan wewenang dan bahkan eksistensi Kemenag itu sendiri sejak dari tingkat pusat sampai daerah. Dari sudut daerah, pemda memiliki ruang otonomi untuk mendistribusikan sumber dana secara efektif dan efesien ke seluruh jenis dan jenjang pendidikan di wilayah setempat. Selain itu, Pemda dapat menghilangkan diskriminasi terhadap madrasah dan, sebaliknya, memperlakukannya sama dengan sekolah umum.

Kedua, Institusi Ditjen Binbaga, Kemenag, diintegrasikan ke dalam Depkemendiknas, dan penyelenggaraan pendidikan agama dan keagamaan diserahkan pada Pemda. Dengan satu atap di bawah Kemendiknas, maka penyelenggaraan termasuk pendanaan dan kualitas pendidikan agama dan keagamaan akan sama dan sejajar dengan sekolah umum.

Dengan satu atap, pendidikan agama dan keagamaan menjadi lebih ter-integrasi ke dalam sistem pendidikan nasional, tidak ada lagi dikotomi kelembagaan dan substansial antara pendidikan agama dan keagamaan dengan pendidikan umum. Juga, diskriminasi yang selama ini ada terhadap pendidikan agama dan keagamaan kemungkinan besar dapat diminimalisasi, walaupun tidak bisa dihilangkan sama sekali.

Ketiga, Menghilangkan paradigma dikotomi antara ilmu agama dan ilmu umum, ilmu tidak bebas nilai, tetapi bebas untuk di 
nilai. Itulah sebabnya diperlukan adanya pencerahan dalam mengupayakan integralisasi keilmuan.

Keempat, Merubah pola pendidikan Islam indoktrinasi menjadi pola partisipatif antara guru dan murid. Pola ini memberikan ruang bagi siswa untuk berpikir kritis, optimis, dinamis, inovatif, memberikan alasan-alasan yang logis, bahkan siswa dapat pula mengkritisi pendapat guru jika terdapat kesalahan. Intinya, pendekatan epistemologi ini menuntut pada guru dan siswa untuk sama-sama aktif dalam proses belajar mengajar. ${ }^{19}$

\section{Penutup}

Pendidikan Islam telah lama dilaksanakan di Indonesia, yaitu mulai sejak masuknya Islam di nusantara ini. Mengenai persoalan ontologi, epistemologi dan aksiologi dalam pendidikan Islam sebenarnya tidak ada masalah akan tetapi ketika ditarik ke konteks ke-Indonesiaan dan perkembangan kebutuhan pasar dewasa ini, maka muncul beberapa problem terkait dengan epistemologi pendidikan Islam.

Eksistensi dikotomi ilmu dalam Agama Islam sebenarnya tidak ada, hanya saja perjalanan sejarah ummat Islam dunia pada umumnya dan secara khusus Indonesia yang menyebabkan pola fikir manusia dan bahkan lembaga pendidikan mempunyai pemahaman dikotomis terhadap ilmu pengetahuan.

Untuk melaksanakan proses pendidikan, diperlukan sebuah konsep, manajemen yang disusun dan di sepakati bersama oleh berbagai lapisan (elemen) masyarakat Indonesia, agar semua tujuan dan cita-cita bangsa tercapai secara optimal sesuai dengan yang diinginkan.

Di Indonesia sendiri, dengan segala keterbatasannya negara mempunyai peran yang signifikan dalam peroses pelaksanaan dan pengembangan pendidikan Islam Indonesia. Gerak perubahan pendidikan Islam di Indonesia bergerak dari alamiah ke rekayasa sosial, dari arah politik ke arah akademik. Perlu waktu yang sekitar 60 tahun yaitu sejak akhir abad ke 19 hingga awal abad ke 20 gerakan alamiah itu bergeser kearah akademik. Hal ini terjadi setelah melalui dinamika yang cukup alot antara romatisisme

19 Moh. Wardi, Problematika Pendidikan Islam Dan Solusi Alternatifnya (Perspektif Ontologis, Epistemologis dan Aksiologis), Tadris Pendidikan Agama Islam STAIN Pamekasan, Vol. 8 No. 1 Juni 2013, 63. 
politik dengan kebutuhan untuk menyediakan pendidikan yang diperlukan untuk mengembangkan ilmu pengetahuan dan kebutuhan pasar.

\section{Daftar Pustaka}

Abdullah, Amin. Islamic Studies di Perguruan Tinggi, (Yogyakarta: Pustaka Pelajar, 2006)

---------------- Pendidikan Dan Upaya Mencerdaskan Bangsa, Paradigma baru Pendidikan, (Jakarta: IISEP, 2008)

Asy'arie, Musa. Filsafat Islam, (Yogyakarta: LESFI, 2008)

Azra, Azyumardi. Dkk. Strategi Pendidikan, (Yogyakarta: Pustaka Pelajar, 2010)

- Paradigma Baru Pendidikan Nasional, (Jakarta: Buku Kompas, 2006)

Darwis, Jamaluddin. Dinamika Pendidikan Islam, (Semarang: Rasail, 2010)

Karim, M., Rusli. Pendidikan Islam di Indonesia, (Yogyakarta: Tiara Wacana Yogya, 1991)

Langgulung, Hasan. Asas-Asas Pendidikan Islam, (Jakarta: Alhusna Zikra, 2002)

Muhaimin, Suti'ah, Sugeng. Manajemen Pendidikan, (Jakarta: Kencana, 2010)

Mas'ud, Abdurrahman. Menggagas Format Pendidikan Nondikotomik, (Yogyakarta: Gama Media, 2002)

Muhaimin. Wacana Pengembangan Pendidikan Islam, (Surabaya: PSAPM, 2004)

Wardi, Moh. Problematika Pendidikan Islam Dan Solusi Alternatifnya (Perspektif Ontologis, Epistemologis dan Aksiologis), Tadris Pendidikan Agama Islam STAIN Pamekasan, Vol. 8 No. 1 Juni 2013.

Yunus, Mahmud, H. Sejarah Pendidikan Islam di Indonesia, (Jakarta: Mutiara Sumber Widya, 1995) 